This is a post-print version of the following published paper:

Hurtado Albir, Amparo; Olalla-Soler, Christian (2016). " Procedures for assessing the acquisition of cultural competence in translator training", The Interpreter and Translator Trainer, Vol. 10 No. 3, pp. 318-342. https://doi.org/10.1080/1750399X.2016.1236561

\title{
Procedures for Assessing the Acquisition of Cultural Competence in Translator Training ${ }^{1}$
}

\begin{abstract}
The aim of this article is to present different procedures (instruments and tasks) for assessing the acquisition of cultural competence in translator training. Firstly, we outline the basis of competence assessment in translator training, advocating a dynamic, multidimensional, criteriabased approach to assessment and explaining the need to use a wide variety of assessment tasks and instruments. Secondly, we define the concepts of culture and cultural competence and set out different proposals, before breaking cultural competence down into four sub-competences (cultural knowledge, cultural knowledge acquisition abilities, culture-related contrastive abilities, and attitudinal sub-competence) and specifying their respective components, which can be used as indicators for assessment purposes. Lastly, we put forward various procedures for assessing the acquisition of cultural competence. We organise these procedures on the basis of nine instruments, such as translation reports, catalogues of cultural references, translation process recordings and cultural portfolios. For each instrument we describe possible assessment tasks, identify assessable aspects, and state which sub-competences of cultural competence it can be used to assess.
\end{abstract}

Keywords: cultural competence, assessment procedures, competence-based training, translator training

\section{Introduction}

Cultural competence is deemed one of the sub-competences of translation competence (TC) in almost every model of the latter, and some translator training centres even teach subjects related to its development. All this gives rise to a number of questions. What does translators' cultural competence consist of? What is its role as a sub-competence of TC? How is it acquired? How can it be taught? How should it be assessed?

We do not intend to answer all of these questions in this article, but rather focus on that of how to assess cultural competence in translator training. To do so, however, the others must be addressed to some extent. We therefore firstly outline the basis of competence assessment in translator training. Then, we look at cultural competence and its acquisition, and set out our proposal regarding its sub-competences and

\footnotetext{
${ }^{1}$ Translated from Spanish by Paul Taylor.
} 
This is a post-print version of the following published paper:

Hurtado Albir, Amparo; Olalla-Soler, Christian (2016). " Procedures for assessing the acquisition of cultural competence in translator training", The Interpreter and Translator Trainer, Vol. 10 No. 3, pp. 318-342. https://doi.org/10.1080/1750399X.2016.1236561

indicators. Lastly, we suggest procedures for the assessment of cultural competence in translator training.

\section{Competence Assessment in Translator Training}

A new pedagogical model called competence-based training $(\mathrm{CBT})^{2}$ has been advocated in recent times in translation training. In CBT, curriculum design revolves around competences, which are conceived as combinations of different types of knowledge, abilities and attitudes.

CBT distinguishes between specific (or discipline-related) competences, which are inherent to a particular discipline, and general (or transversal) competences, which apply to all disciplines (e.g. Lasnier 2000; González and Wagenaar 2003; Yániz and Villardón 2006; Cano 2015). Each discipline must determine the general and specific competences that define the professional profile(s) by which it is characterised ${ }^{3}$. While cultural competence is a general competence in some kinds of training, it is, as we shall see, a specific competence in the case of translator training.

Competences must be operationalised in order to plan teaching in a way that is conducive to their acquisition. Many proposals have been made regarding competence operationalisation (e.g. Lasnier 2000, 46ff.; Yániz and Villardón 2006). In the translation arena, the proposal developed by Hurtado Albir (2007, 2008, 2015a, 2015b) is based on those proposals and takes the following aspects into account: (1) the definition of the competence; (2) the elements of the competence, i.e. observable behaviours that are part of the competence and can be used as indicators for its assessment; (3) associated content; (4) possible tasks for competence acquisition (teaching methods); (5) assessment procedures.

Given our focus on assessment procedures, some aspects of operationalisation (especially methodology) are not covered in this paper. Nevertheless, for the purpose of discussing assessment procedures, it is necessary to define competences and indicators, which are vital to determining what is to be assessed.

\subsection{Competence Assessment}

CBT features an integrated approach to teaching, learning and assessment, where assessment is regarded as a tool for learning rather than as a mere grading system.

There are different types of assessment, and they can be classified by purpose, timing and assessor (Table 1).

Table 1. The different types of assessment (Galán-Mañas and Hurtado Albir 2015, 2-4)

\begin{tabular}{|c|l|}
\hline Purpose: $\boldsymbol{w h y}$ & $\begin{array}{l}\text { Summative assessment (grading) } \\
\text { Diagnostic assessment (identifying students' characteristics) } \\
\text { Formative assessment (establishing how a learning process is progressing) }\end{array}$ \\
\hline Timing: $\boldsymbol{w h e n}$ & $\begin{array}{l}\text { Initial assessment (before a learning process begins) } \\
\text { Continuous assessment (throughout a learning process) } \\
\text { Final assessment (at the end of a learning process) }\end{array}$ \\
\hline \multirow{2}{*}{ Assessor: $\boldsymbol{w h o}$} & $\begin{array}{l}\text { Self-assessment (students assess themselves) } \\
\text { Peer assessment (students assess one another) } \\
\text { Hetero-assessment (assessment by an assessor whose level of knowledge or skills } \\
\text { differs from that of the assessee, e.g. a lecturer assessing a student or a customer } \\
\text { assessing a professional) }\end{array}$ \\
\hline
\end{tabular}

\footnotetext{
${ }^{2}$ See Hurtado Albir $(2007,2008)$ for further information on CBT and its application to translation teaching.

${ }^{3}$ Hurtado Albir $(2007,2008)$ proposes six categories of specific competences for translator training (methodological and strategic; linguistic-contrastive; extralinguistic; occupational; instrumental; and translation problem-solving competences), which represent the first operationalisation of PACTE's TC model (PACTE 2003).
} 
This is a post-print version of the following published paper:

Hurtado Albir, Amparo; Olalla-Soler, Christian (2016). " Procedures for assessing the acquisition of cultural competence in translator training", The Interpreter and Translator Trainer, Vol. 10 No. 3, pp. 318-342. https://doi.org/10.1080/1750399X.2016.1236561

To make comprehensive assessment of learning possible, translator training ought to include all the above types of assessment. Additionally, assessment in such training should seek to (Hurtado Albir 2008, 2015a, 2015b):

- Assess the product and the process. Both the result of performing a task (a translation, a revision, a report, etc.) and the process followed in doing so should be assessed. To that end, it is necessary to work with assessment tasks and instruments which provide information on the process (translation problems identified, approaches to solving them, documentary resources used, information looked up, strategies used, etc.).

- Assess knowledge, abilities and attitudes. To do so, a variety of tasks and instruments which provide information of different kinds must be used. A dynamic, multidimensional approach to assessment is thus required.

- Apply specific assessment criteria, which are essential in that they act as a grading guide for lecturers and make students aware of what is expected of them. It is thus necessary to design assessment rubrics that describe criteria and performance, establishing grading scales. Rubrics not only make it possible to appraise assessment task performance, but also simplify providing students with feedback and allow for selfassessment and peer assessment.

- Emphasise the role of formative assessment. Such assessment is aimed at obtaining information on a learning process to make students aware of their progress and enable lecturers to evaluate their teaching activity (content, methods, progression, etc.). Tasks involving the appraisal of what students have learned must therefore feature constantly.

- Promote student self-assessment. Students' reflection on and appraisal of their own learning process (through reports, worksheets or questionnaires) is important for both students themselves and lecturers. As future professionals, translation students must be capable of such appraisal for process enhancement purposes. From a lecturer's perspective, student self-assessment provides information on a student's perception of their own learning process, as well as on possible flaws in teaching activity.

- Promote assessment from different perspectives. In addition to lecturers assessing students and students assessing themselves, it is necessary, in the interests of cooperative learning, to foster peer assessment, involving students appraising one another's work so as to learn from their classmates' correct solutions and errors. This is conducive to more feedback.

\subsection{The need for a variety of assessment tasks and instruments}

The most common assessment task in translation teaching is probably translating texts, an activity that can provide information on different competences, including a student's command of the target language, comprehension of the foreign language involved, and ability to solve translation problems. However, it only gives information on translation's product (the student's chosen solutions) in a specific case. It does not offer a sufficient insight into the extent of the student's TC, as it reveals nothing about the process they have 
This is a post-print version of the following published paper:

Hurtado Albir, Amparo; Olalla-Soler, Christian (2016). " Procedures for assessing the acquisition of cultural competence in translator training", The Interpreter and Translator Trainer, Vol. 10 No. 3, pp. 318-342. https://doi.org/10.1080/1750399X.2016.1236561

followed, the problems they have identified, the strategies they have used to solve those problems or their implicit knowledge of translation. Other assessment instruments and complementary tasks which furnish further information on students are therefore required, as proposed by Galán-Mañas and Hurtado Albir (2015). The most suitable instruments and tasks depend on the competences and indicators to be assessed in each case. In Section 4 we will discuss the range of instruments available for assessing cultural competence.

\section{Cultural Competence in Translator Training}

\subsection{The Concept of Culture and its Implications for Teaching}

The concept of culture has been researched in Anthropology since the $19^{\text {th }}$ century. A classic, frequently quoted definition is that of Tylor $(1871,1)$ : "Culture, or civilization [...] is that complex whole which includes knowledge, belief, art, law, morals, custom, and any other capabilities and habits acquired by man as a member of society." Culture has since been defined in many different ways, depending on the aspects each author has sought to emphasise. Robinson (1988, 7-13) organised the definitions of culture compiled by Kroeber and Kluckhohn (1952) into four approaches, based on the aspect of culture on which they focus:

- The behaviourist approach, which defines culture as a selection of facts about what people do and do not do.

- The functionalist approach, which looks for the reason for which people behave in a specific way.

- The cognitive approach, which seeks to explain why the brain links the cause of a form of behaviour with its effect.

- The dynamic approach, according to which culture is not static and intercultural communication consists of mediation between two dynamic cultural systems whose values, customs and behavioural rules are in a constant dialectic process between internal models and reality.

There is a similar situation in Translation Studies. Some authors prefer to think of culture as cultural products, tangible and intangible alike, such as instruments, artistic productions, typical kinds of food, and legal, economic and educational systems (Newmark 1988; Nida 2005; etc.). Others (Vermeer 1992; Witte 2000; Nord 2005; etc.) favour a cognitive perspective mainly based on Goodenough's definition:

"A society's culture consists of whatever it is one has to know or believe in order to operate in a manner acceptable to its members. Culture is not a material phenomenon; it does not consist of things, people, behavior, or emotions. It is rather an organization of these things. It is the form of things that people have in mind, their models for perceiving, relating, and otherwise interpreting them." (Goodenough 1957, 167)

On the basis of Hall's iceberg model (1959), Katan (2009) organises definitions of culture into hierarchical frames that run from the most to the least visible aspects of culture: 
This is a post-print version of the following published paper:

Hurtado Albir, Amparo; Olalla-Soler, Christian (2016). " Procedures for assessing the acquisition of cultural competence in translator training", The Interpreter and Translator Trainer, Vol. 10 No. 3, pp. 318-342. https://doi.org/10.1080/1750399X.2016.1236561

- Technical culture. This frame corresponds to the most visible aspects of culture. Here, the translator concentrates on translating a text's cultural references, seen as phenomena that exist in a single culture with a certain function. This is where definitions such as those of Newmark (1988) and Nida (2005) belong.

- Formal culture. The definitions of culture in this frame focus on what is normal or appropriate in a society. Culture acts as a model that guides the practices of society (i.e. of the technical culture). Among the definitions in this frame are that of Vermeer (1989) and the concept of norms developed by Chesterman (1993) and Toury (1995).

- Informal culture. This is the least observable frame. Its definitions of culture revolve around the core values and beliefs of cultural systems. It includes Lefevere and Bassnett's notion of the cultural turn (1990) and Taft's concept of mindshifting (1981) in translation as a bicultural practice.

Katan situates culture's influence on society and institutions outside the frames in question. This is where polysystem theory (Even-Zohar 1990), Venuti's concept of foreignization (1998) and Baker's narrative theory (2006) can be found.

In our opinion, the concept of culture should be broad, encompassing both cultural products and cognitive aspects rather than focusing exclusively on one or the other. We thus propose a definition that incorporates each of those perspectives, and also stresses the dynamic and social nature of culture:
"A culture is a system of norms, values, standards and behavioural models that is socially acquired and shared by a group of individuals and is developed in a cognitive context. Through this system, a group of individuals perceives and modifies the natural and artificial world in certain ways; it develops sub-systems for the organisation of behaviour, of the natural world, of patrimony, of societal structures and of linguistic and communicative needs. A culture constantly evolves through contact with other cultural systems and because of changes in the perceived natural world." (Olalla-Soler 2015, 90)

Culture thus works as a cohesive system among individuals by guiding the processes of perception, judgment, attribution and decision-making and by socially favouring certain attitudes. It also provides a group of individuals with a common framework for perceiving, modifying and interpreting the world and, therefore, for establishing a shared yet individually developed reality.

In education, we can deduce that different conceptions of culture will entail different curriculum content (Table 2).

Table 2. Conceptions of culture and curriculum content

\begin{tabular}{|c|c|}
\hline Conception & Curriculum content \\
\hline Cultural products & $\begin{array}{l}\text { Habits and behaviours; artistic productions; models of social organisation; historical } \\
\text { events and figures; ways of dressing; food and drink; etc. }\end{array}$ \\
\hline Cognitive aspects & $\begin{array}{l}\text { Cultural system organisation models; models for perceiving and interpreting individuals, } \\
\text { products, behaviours and other cultural systems; etc. }\end{array}$ \\
\hline $\begin{array}{l}\text { Integrative } \\
\text { conception }\end{array}$ & $\begin{array}{l}\text { Habits and behaviours; artistic productions; models of social organisation; historical } \\
\text { events and figures; ways of dressing; food and drink; etc. } \\
\text { Cultural system organisation models; models for perceiving and interpreting individuals, } \\
\text { products, behaviours and other cultural systems; etc. } \\
\text { Identifying cultural levels that may exist within a given culture. } \\
\text { Cultural dynamism in relation to space, time and contact with other cultures. } \\
\text { Social aspects (cohesion and distinction between human groups, assimilation of cultural } \\
\text { traits, etc.). }\end{array}$ \\
\hline
\end{tabular}


This is a post-print version of the following published paper:

Hurtado Albir, Amparo; Olalla-Soler, Christian (2016). " Procedures for assessing the acquisition of cultural competence in translator training", The Interpreter and Translator Trainer, Vol. 10 No. 3, pp. 318-342. https://doi.org/10.1080/1750399X.2016.1236561

We feel it is important, when designing curriculum content, to bear in mind that it is impossible to cover a culture in its entirety (Witte 2000,177-178), so appropriate content must be selected in each case.

\subsection{Cultural Competence and Translation Competence}

Cultural competence is deemed one of the sub-competences of TC in almost every model of the latter $^{4}$ (Bell 1991; Kiraly 1995; Cao 1996; Hurtado Albir 1996; Hatim and Mason 1997; Neubert 2000; Kelly 2005; Shreve 2006; Katan 2008; Göpferich 2008). PACTE's model, which has been empirically validated (see Hurtado Albir in press), identifies five sub-competences (the bilingual, extralinguistic, knowledge of translation, instrumental and strategic subcompetences) and various psycho-physiological components of TC (PACTE 2003). Cultural competence is part of the extralinguistic sub-competence, which is described as "predominantly declarative knowledge, both implicit and explicit, about the world in general and special areas. It includes: (1) bicultural knowledge (about the source and target cultures); (2) encyclopaedic knowledge (about the world in general); (3) subject knowledge (in specific areas)." (PACTE 2003, 58-59). Olalla-Soler (2015; in press) is using the model in question to conduct experimental research on cultural competence acquisition.

While many models of TC have been put forward, few proposals have been made regarding how to define and model translators' cultural competence. It is also worth noting that some authors refer to intercultural competence rather than cultural competence. It is also worth noting that some authors refer to intercultural competence (Katan 2001; PICT 2012) rather than cultural competence in order to state more explicitly the idea that there is a constant movement between two cultures. However, this constant bicultural movement is also present in other authors that use the term cultural competence as we do. We believe that this is more a matter of designation rather than of content (see for example Witte 1987).

Witte defines translation-specific cultural competence as:

"the ability of consciously learning something which is not yet known in both the own and the other (foreign) culture, and the ability to relate both cultures to each other, compare them with the aim of a purposeful and situation adequate reception and production of behaviour for the needs of at least two interacting partners from two different cultures in order to achieve communication between these interacting partners." (2000, 172; translated in Schäffner 2004, 488-489)

Witte divides the competence in question into two sub-competences:

- General cultural competence: awareness of the problems caused by differences in behaviour in inter- and intracultural communication and the conditions that influence such behaviour.

- Specific cultural competence: the main competence, which is acquired in relation to a particular pair of cultures and languages but can be applied to other cultures.

\footnotetext{
${ }^{4}$ As far as we are aware, Pym's (1992) minimalist model and Risku's (1998) modular conception of TC are the only two exceptions.
} 
This is a post-print version of the following published paper:

Hurtado Albir, Amparo; Olalla-Soler, Christian (2016). " Procedures for assessing the acquisition of cultural competence in translator training", The Interpreter and Translator Trainer, Vol. 10 No. 3, pp. 318-342. https://doi.org/10.1080/1750399X.2016.1236561

According to Witte, cultural competence is based on a process of consciously learning about a pair of cultures and applying the acquired knowledge to help two members of different cultures communicate with each other.

Katan, meanwhile, observes that intercultural competence addresses:

"the motivation, the values and the beliefs involved when participating in another community. Hence it is the intercultural skills which will constrain or promote the immanent communicative abilities." $(2001,296)$

In Katan's opinion, intercultural competence is based on metacognitive traits, such as respect, empathy, flexibility, patience and interest.

It seems to us that these models are based solely on knowledge (of the declarative kind, i.e. know-what) or on the development of metacognitive traits (according to Katan) to be applied, once acquired, to intercultural communication. In our view, however, translators' cultural competence consists of more than just knowledge and has a permanent connection with the subcompetences of TC (see Section 3.4).

We therefore define cultural competence as:

"the translator's abilities to effectively arrange his/her knowledge about a source culture and that of a target culture and to contrast them in relation to a cultural phenomenon perceived in a source text in order to achieve an acceptable solution in a target text. The translator's cultural competence is related to the other subcompetences that make up translation competence." (Olalla-Soler 2015, 94)

\subsection{Cultural Competence in Translator Training}

Few authors have put forward proposals regarding the acquisition of cultural competence in translator training. The three most relevant proposals, in our opinion, are those of Witte (2000), Katan (2009) and the European project Promoting Intercultural Competence in Translators (PICT) (2012).

Witte (2000, 175-176) identifies six stages in the development of cultural competence:

(1) awareness of the existence of cultural differences in behaviour and in the interpretation and evaluation of behaviour, as well as of how they can potentially affect intercultural communication;

(2) the ability to cognitively accept such differences;

(3) the ability to recognise and accept the influence of one's own culture;

(4) the ability to be aware of and, if necessary, modify one's perception of one's own culture and the foreign culture involved;

(5) the ability to be aware of and, if necessary, modify one's active behaviour in relation to one's own and the foreign culture;

(6) the ability to interpret and produce situation-appropriate behaviours, so as to enable two interacting parties to communicate in a way that fulfils their needs.

Katan (2009) distributes the sub-competences of intercultural competence between two cycles of university studies in Language Mediation in Italy: 
This is a post-print version of the following published paper:

Hurtado Albir, Amparo; Olalla-Soler, Christian (2016). " Procedures for assessing the acquisition of cultural competence in translator training", The Interpreter and Translator Trainer, Vol. 10 No. 3, pp. 318-342. https://doi.org/10.1080/1750399X.2016.1236561

- First cycle (three-year degree): cognitive competencies (know, understand and apply):

- 1. Own/other cultural locatedness: development of the translator's own toleration of difference and intercultural toleration of difference.

- 2. Linguaculture: work on the translation of rich points (Agar 1994, 60) involving different correspondence levels. Rich points are terms that have a heavy cultural load and can cause intercultural misunderstanding.

- 3. Cultural grammar: work on making the hidden logical world implicit in the context of the utterance explicit.

- Second cycle (mediation): metacognitive competencies (analyse, synthesise, evaluate):

- 4. Mindshifting: trainees are encouraged to associate fully with 'own' and 'other' socio-cultural worlds of discourse.

- 5. Mediation: development of compensation strategies and the ability to reflect on the implications of the choices made when translating.

- 6. Openness to difference: competence in "uncertainty management" is acquired and risk-taking is encouraged.

The proposals of Witte and Katan differ greatly in terms of the content they advocate. Witte focuses on awareness of cultural differences, the acquisition of knowledge about behaviours, and application according to the purpose of communication and the aims of its participants. Katan's proposal includes aspects such as cultural relativism and its influence on translation too (particularly in the first cycle), but goes further than Witte's where application to translation is concerned (particularly in the second cycle).

The PICT project set out to produce a curriculum framework and sample pedagogical and assessment materials to facilitate the inclusion of intercultural communication in postgraduate translation programmes in the EU. The framework was intended to help universities develop their own syllabuses for a stand-alone module on intercultural communication or for incorporating such communication into other modules, such as translation courses.

The framework identifies three dimensions of intercultural competence and breaks them down into various sub-dimensions, for each of which it establishes three levels of achievement. The three dimensions are (PICT 2012, 6-7):

- the theoretical dimension: a specially shaped conceptual and terminological framework that should become part of the students' overall competence and critical awareness of their role;

- the textual dimension: the skills students should be able to apply on the basis of their theoretical knowledge to the actual process/product of translating from one culture into another;

- the interpersonal dimension: students' attitudes of openness and the ability to be nonjudgemental in relation to both source and target cultures.

While we consider all three proposals useful for the acquisition of cultural competence in translator training, we feel they have two questionable aspects. Firstly, none of them takes into account the fact that students cannot possibly acquire all knowledge about a 
This is a post-print version of the following published paper:

Hurtado Albir, Amparo; Olalla-Soler, Christian (2016). " Procedures for assessing the acquisition of cultural competence in translator training", The Interpreter and Translator Trainer, Vol. 10 No. 3, pp. 318-342. https://doi.org/10.1080/1750399X.2016.1236561

pair of cultures. Witte does mention this in her book $(2000,177-178)$ but offers no alternative for the acquisition of knowledge not deemed relevant enough to be dealt with in the classroom. PICT's curriculum framework does not actually make specific mention of knowledge of working cultures, merely linking it to the theoretical aspects of intercultural communication. As it is impossible to cover all the fields of a culture and all its levels (paraculture, diaculture and idioculture), there is an obvious need to select what knowledge is to be acquired. Secondly, none of the proposals develops documentation strategies or abilities related to the acquisition of cultural knowledge (see Section 3.4.2.).

In our view, the goal of translator training is not for students to know absolutely everything about their working cultures or how to behave like members of those cultures. It is rather for them to be able to use appropriate documentation sources effectively, and to have sufficient knowledge to identify cultural references corresponding to the source culture and the necessary abilities to transfer them to the target culture in line with a translation brief.

\subsection{Sub-competences for the Acquisition of Cultural Competence in Translator Training}

Based on the previous considerations, we believe that the acquisition of cultural competence in translator training requires three specific sub-competences (cultural knowledge, cultural knowledge acquisition abilities and culture-related contrastive abilities) and one general subcompetence (attitudinal sub-competence) (see Figure 1$)^{5}$.

Figure 1. Sub-competences for the acquisition of cultural competence in translator training (Olalla-Soler in

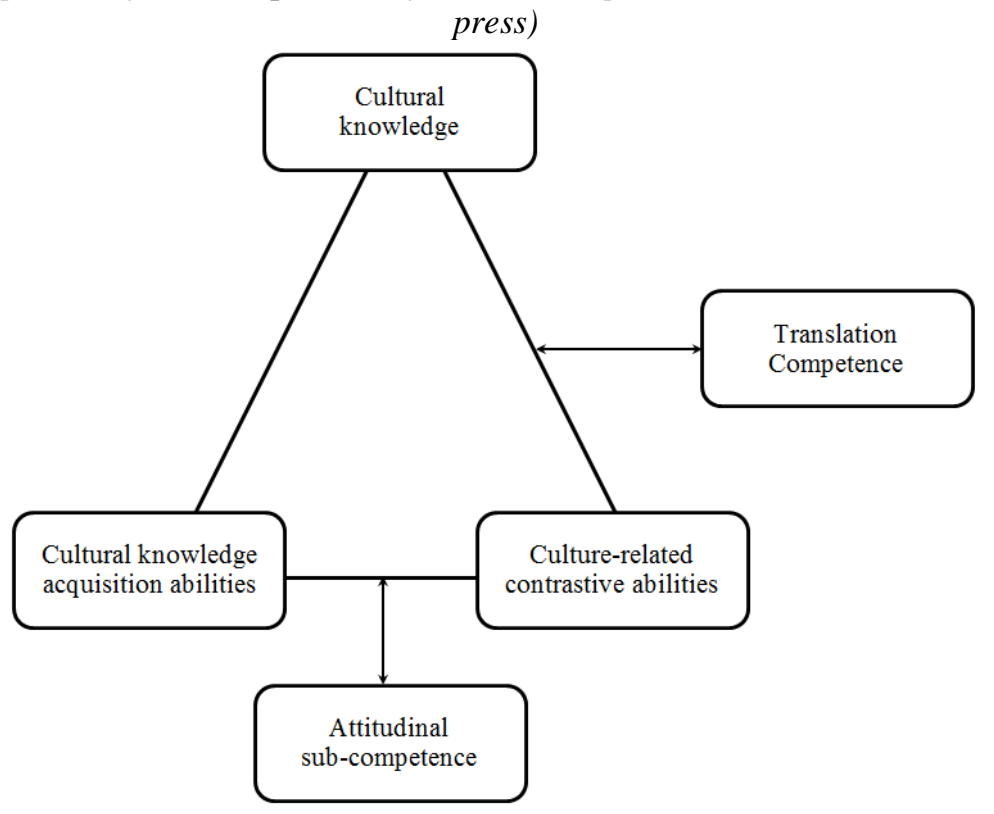

We define each of the sub-competences in question below and identify its components, which can be used as indicators for assessment purposes.

\footnotetext{
${ }^{5}$ Olalla-Soler (2015; in press) is carrying out experimental research on cultural competence acquisition with a view to validating the model proposed here.
} 
This is a post-print version of the following published paper:

Hurtado Albir, Amparo; Olalla-Soler, Christian (2016). " Procedures for assessing the acquisition of cultural competence in translator training", The Interpreter and Translator Trainer, Vol. 10 No. 3, pp. 318-342. https://doi.org/10.1080/1750399X.2016.1236561

\subsubsection{Cultural Knowledge}

This consists of declarative knowledge about both the source and target cultures. A lack of the declarative knowledge necessary to identify and resolve a specific cultural reference will generally result in failure to notice the reference and come up with a solution suited to a translation's purpose. Witte's proposal regarding the development of cultural competence (2000) does not specifically list this sub-competence, although it does refer to translators' cultural knowledge. Similarly, Katan (2009) does not specifically include cultural knowledge among his proposed sub-competences of intercultural competence. PICT (2012) does not explicitly mention cultural knowledge either, although it does make references to it in the textual dimension (e.g. in the comparative analysis of cultural issues from source and target audiences sub-dimension).

The knowledge this sub-competence includes depends on the definition of culture applied. In the case of our definition, its components could be:

- Knowing about the organisation of the natural environment: flora, fauna, atmospheric phenomena, landscapes, place names, etc.

- Knowing about the organisation of cultural heritage: characters (historical and fictitious), historical facts, religions, festivities, popular beliefs, folklore, monuments, fine arts, games, proper names, tools and objects, agricultural and farming techniques, urbanism, military strategies, transportation, etc.

- Knowing about the organisation of society: (1) conventions and social habits: politeness and honorific language, table manners, dressing and talking, fashion and clothing, moral values, gestures and greetings, etc. (2) social organisation: political, legal and educational systems, occupation, calendar, units of measurement, etc.

- Knowing about linguistic and communicative requirements: transliterations, proverbs, idioms, accepted metaphors, interjections, curse words, etc.

- Being familiar with models of behaviour, values and ideas.

Our description of the first four components is based on Molina's description of the fields of culture (2001,91-95), which are the natural environment, cultural patrimony, social culture and linguistic culture.

\subsubsection{Cultural Knowledge Acquisition Abilities}

Information acquisition abilities and documentation strategies play a crucial role in compensating for trainee translators' lack of cultural knowledge.

Developing effective documentation strategies is vital to improving the process of translating cultural references. It is necessary to know what to search for, how and where to do so, and how to evaluate documentation sources. This sub-competence does not feature in any of the proposals referred to in Section 3.3.

The essential strategies and abilities that make up this sub-competence are:

- identifying documentation-related needs;

- planning searches to enhance effectiveness;

- $\quad$ wording queries appropriately to perform effective searches; 
- evaluating documentation sources;

- evaluating search results;

- applying search improvement procedures;

- broadening the range of documentation sources used.

\subsubsection{Culture-related Contrastive Abilities}

Students need to develop abilities to compare their working cultures with one another, so as to be able to interpret cultural references from both the source and target culture perspectives and to resolve cultural translation problems. Contrastive abilities are also vital for detecting cultural references that might otherwise go unnoticed. This sub-competence is similar to the metacognitive competencies proposed by Katan (2009). Witte (2000) includes it in her proposal too, although with a focus on interpreting and producing culturally appropriate behaviour. In the case of PICT (2012), this sub-competence would be part of the textual dimension. The fundamental contrastive abilities are:

- anticipating possible translation problems caused by cultural interference;

- using knowledge about the source and target cultures to identify, interpret and evaluate cultural references;

- checking cultural references against knowledge of the source and target cultures;

- $\quad$ using appropriate strategies to resolve cultural translation problems.

\subsubsection{Attitudinal Sub-competence}

This refers to attitudinal traits that play a part in relativising one's own culture (i.e. awareness of its influence in all aspects of one's social life) and determining the different cultural levels that may exist within a given culture. This sub-competence is similar to PICT's interpersonal dimension (2012). It is also partially included in Witte's proposal regarding the development of cultural competence (2000) and in Katan's cognitive competencies (2009). The most important attitudinal components are:

- being aware of the influence of one's own culture on one's perception, interpretation and evaluation of other cultures;

- empathising with other cultural groups;

- being flexible in situations of possible cultural conflict;

- accepting cultural differences;

- accepting and modifying cultural prejudices.

Our model attributes great importance to having cultural knowledge, and also to cultural knowledge acquisition abilities, as they are necessary for the application of culture-related contrastive abilities, which are involved in looking for equivalences in the translation process. 
This is a post-print version of the following published paper:

Hurtado Albir, Amparo; Olalla-Soler, Christian (2016). " Procedures for assessing the acquisition of cultural competence in translator training", The Interpreter and Translator Trainer, Vol. 10 No. 3, pp. 318-342. https://doi.org/10.1080/1750399X.2016.1236561

\section{Cultural Competence Assessment Procedures in Translator Training}

To assess cultural competence's sub-competences and their different components, a dynamic, multidimensional approach designed to evaluate both the product and the process must be taken to assessment, applying the principles set out in Section 2.

The competence and sub-competences mentioned in the previous section can be assessed by means of the instruments presented in this one. The same instruments may also be used when working on the basis of other definitions of culture or models of cultural competence.

Procedures for assessing the acquisition of cultural competence in translator training can be varied. We will now look at some potential assessment instruments, describe (where appropriate) possible assessment tasks that can be designed with these instruments, and indicate aspects that could be included in assessment rubrics. All the tasks described can be used for grading purposes (summative assessment), self-assessment, or peer, formative or diagnostic assessment ${ }^{6}$.

\subsection{Texts}

Texts can be used to design cultural competence assessment tasks involving translating, analysing, or writing commentaries or reports.

Texts used for translation tasks must contain prototypical problems caused by cultural references. When selecting a text, consideration must be given to the objectives corresponding to each level of competence and the cultural fields assessment is to cover. A single field or various fields may be chosen, depending on the objectives of the assessment.

Box 1. Example of a text containing prototypical cultural problems (for translation or analysis)

\section{Lautstark gegen die Ostalgie [linguistic culture]}

Geschäftemacher posieren an der ehemaligen Mauer in Berlin in DDR-Uniformen. SED-Opfer protestieren am Jahrestag des Mauerbaus gegen diese Vermarktung der Diktatur

Die Männer sehen müde aus, sie haben trotz des Kaisergeburtstagswetters graue Gesichter und graue Haare. Sie sitzen auf einem Geländer vor dem S-Bahnhof Potsdamer Platz. Sie recken Schilder in die Höhe. "138 Tote an der Mauer", "Verbot von DDR-Symbolen jetzt" und "Alles schon vergessen" steht auf den Transparenten.

Die Alten haben nicht vergessen. Deswegen sind sie hierher gekommen, auf den Platz im Herzen der Spreemetropole [natural environment], der bis 1989 geteilt und eine Ödnis war. "Los geht's", ruft einer, und dann marschieren die Alten los. Ihre Müdigkeit ist vergessen. Sie haben eine Mission.

40 Teilnehmer laufen einige Meter zu den Mauerfragmenten, die am Rande des Platzes stehen. Sie drängen sich an asiatischen und amerikanischen Touristen vorbei, bilden vor den Mauerresten einen Halbkreis und verhindern, dass zwei junge Männer in Grenzeruniformen [cultural heritage] auf einem Boxer-Kardan sich weiter mit Touristen fotografieren lassen und deren Reisepässe mit einem "Original DDR-Visum" des Unrechtsstaats [social culture] versehen.

Wegen der Schauspieler und der DDR-"Verherrlichung", wie sie es nennen, sind die Alten hier. Sie sind Opfer des DDR-Regimes, haben in Haft gesessen, die meisten wegen Republikflucht. Sie sind empört, dass "Ostalgier" und Geschäftemacher ein fast beschauliches, skurriles Bild der SED-Diktatur zeichnen. Und sie sind wütend, dass Studenten in die Rolle von Beamten des untergegangenen Arbeiter- und Bauernstaates [social culture] schlüpfen, um Geld zu verdienen. [...]

Aus Lautstark gegen die Ostalige (bearbeitet), von Hauke Friederichs. Die Zeit (13.8.2009)

Quelle: http://www.zeit.de/online/2009/34/berliner-mauer-streit?page=1

\footnotetext{
${ }^{6}$ The PICT (2012) website includes eight tasks for assessing the acquisition of intercultural competence.
} http://www.pictllp.eu/en/assessment-material 
This is a post-print version of the following published paper:

Hurtado Albir, Amparo; Olalla-Soler, Christian (2016). " Procedures for assessing the acquisition of cultural competence in translator training", The Interpreter and Translator Trainer, Vol. 10 No. 3, pp. 318-342. https://doi.org/10.1080/1750399X.2016.1236561

It is also possible to design other assessment tasks besides translating texts in the strict sense. Examples include gist translation (summarising a source text in the target language), extended translation (adding to a source text's information in the target language) and adapted translation (adaptation to a different readership). It is important, as we shall see, that the translation of a text be accompanied by a report (commented translation) that provides an insight into the process followed.

Assessable aspects include:

- $\quad$ solutions to cultural references;

- appropriateness to brief.

Tasks involving the analysis of one or more texts allow students to work on identifying and categorising cultural references (i.e. indicating their nature) and explaining their translationrelated implications (the problems they pose, possible solutions, etc.).

Assessable aspects include:

- identification of cultural references;

- categorisation of cultural references;

- identification of translation problems posed;

- possible solutions.

Another possible assessment task consists of writing commentaries on texts. Commentaries are a good instrument for assessing a student's ability to reflect on culture-related attitudes, such as cultural relativism, ethnocentrism, cultural stereotypes and prejudices against other cultures.

\section{Box 2. Example of a text for a commentary task}

Read the text below and write a commentary on it by answering the questions that follow.

When you meet the Germans you will probably think they are very much like us. They look like us, except that there are fewer of the wiry type and more big, fleshy, fair-haired men and women, especially in the north. But they are not really so much like us as they look.

The Germans have, of course, many good qualities. They are very hard working and thorough; they are obedient and have a great love of tidiness and order. [...] But for centuries they have been trained to submit to authoritynot because they thought their rulers wise and right, but because obedience was imposed on them by force.

[...] You will run across Germans who are genuinely ashamed of being Germans. Even before Hitler made Germany universally hated, they had a sense of national inferiority. They felt that other nations, like the British, Americans and French, were somehow ahead of them. There is little doubt that Hitler realised this, and used his theory of the Master Race to overcome it.

Foreign Office. 2005. Instructions for British Servicemen in Germany, 1944. London: The Bodleian Library, University of Oxford.

- Explain the text's historical context.

- In that context, what was the nature of the relationship between the two cultures described?

- How are the Germans described?

- How are the British described?

- Do you think there is much truth in the latter description or is it based on stereotypes? Explain your answer.

- Do the British have prejudices? If so, what are they? 
Assessable aspects include:

- identification of the influence of one's own culture on one's perception, interpretation and evaluation of other cultures;

- empathy with other cultural groups;

- attitude in situations of possible cultural conflict;

- acceptance of cultural differences;

- acceptance and modification of cultural prejudices.

A further possible type of assessment task is to write reports on texts that deal with specific cultural aspects or on theoretical texts about culture-related matters (interculturalism, models of culture, etc.).

Assessable aspects include:

- ideas set out;

- clarity and concision in setting out ideas;

- rigour of arguments supporting the critical evaluation made;

- report composition, structure and presentation.

This instrument can be used to assess cultural knowledge, culture-related contrastive abilities, and attitudinal sub-competence.

\subsection{Translations}

Completed translations of texts containing prototypical cultural problems are another instrument for assessing the acquisition of cultural competence. They can be used to design assessment tasks based on translation analysis, involving either a single translation or various translations (comparative translation analysis), which may be in the same language or different languages (multilingual) and from the same period (synchronic) or different periods (diachronic) (Hurtado Albir 2001/2011, 157, 643). Students can also perform revisions of such translations.

Assessable aspects include:

- identification of cultural references;

- categorisation of cultural references;

- identification of correct solutions;

- identification and categorisation of errors;

- proposed solutions (in the case of translation revision).

This instrument can be used to assess culture-related contrastive abilities.

\subsection{Translation Reports: Commented Translation}

As indicated previously, commented translation, i.e. translating a text and writing an accompanying translation report, is particularly useful for assessing a student's competences (Delisle 1980; Hurtado Albir 1996; García Álvarez 2007; Presas 2012; 
This is a post-print version of the following published paper:

Hurtado Albir, Amparo; Olalla-Soler, Christian (2016). " Procedures for assessing the acquisition of cultural competence in translator training", The Interpreter and Translator Trainer, Vol. 10 No. 3, pp. 318-342. https://doi.org/10.1080/1750399X.2016.1236561

among others). In such reports, students should identify parts of the text containing culturerelated problems; identify and classify cultural references; explain the process followed in resolving them, justify their proposed solutions, indicate the translation techniques used and suggest alternative solutions; identify possible errors made; and give details of the documentary resources used, the queries performed, the time spent on the task, how they planned their work, etc. A worksheet with questions can be used to guide students in producing their reports.

Commented translation is important because it allows for the assessment of the process each student has followed to resolve a text's cultural references rather than merely of their proposed solutions (the end product). It thus makes it possible to distinguish between students who have identified a cultural reference and its nature (even if they have not resolved it successfully) and those who have not even spotted it.

\section{Box 3. Examples of guiding questions for commented translation}

- $\quad$ Select the text's five most notable cultural references and explain your choices. Describe the translation problems they pose and state why they do so.

- Justify your proposed solutions to the cultural references in question and suggest alternatives.

- What factors did you consider when resolving the cultural references? Did you try to reproduce their vocabulary and syntax? Did you try to transmit their meaning? Why?

- $\quad$ Describe the steps you followed to resolve each cultural reference.

- Identify the documentary resources you used. Explain why you used them and how they helped you.

- $\quad$ Are you satisfied with your solutions? Explain your answer. Do you feel you have failed to resolve anything adequately?

- How could you improve your ability to resolve cultural references when translating?

Assessable aspects include:

- translation solutions for cultural references;

- information in report with regard to:

- cultural references identified;

- categorisation of cultural references;

- justification of solutions and possible alternatives;

- documentation used and queries performed;

- $\quad$ reflection on the process (appraisal of result, possible errors made, etc.).

- report composition, structure and presentation.

This instrument can be used to assess cultural knowledge, cultural knowledge acquisition abilities, and culture-related contrastive abilities.

\subsection{Reports on Cultural References}

Another possibility is to write reports on cultural references corresponding to a specific field or different fields, or on culture-related false friends. This kind of task is geared to assessing a student's knowledge of cultural references and ability to locate documentary resources on them. 
This is a post-print version of the following published paper:

Hurtado Albir, Amparo; Olalla-Soler, Christian (2016). " Procedures for assessing the acquisition of cultural competence in translator training", The Interpreter and Translator Trainer, Vol. 10 No. 3, pp. 318-342. https://doi.org/10.1080/1750399X.2016.1236561

Assessable aspects include:

- $\quad$ knowledge of the relevant field(s);

- documentation used;

- report composition, structure and presentation.

This instrument can be used to assess cultural knowledge and cultural knowledge acquisition abilities.

\subsection{Catalogue of Cultural References}

Catalogues of cultural references are another possible assessment instrument. Cultural references can be catalogued on the basis of searches for information (reading texts) or the tasks performed during a course. Each reference in a catalogue should be contextualised and accompanied by details of its nature, a proposed translation with supporting arguments, information on the technique used to resolve it and possible solutions in other contexts.

Assessable aspects include:

- quantity and diversity of cultural references catalogued;

- suitability of proposed translations;

- justification of proposed translations;

- techniques used to translate cultural references.

This instrument can be used to assess cultural knowledge acquisition abilities and culturerelated contrastive abilities.

\subsection{Cultural Knowledge Questionnaires}

Questionnaires testing cultural knowledge can be used to assess the knowledge students acquire about a source or target culture during their training. They may focus on a specific aspect of the culture concerned (a cultural field, a political, legal or economic system, etc.) or even cover all its fields.

Such questionnaires generally feature multiple-choice questions, sometimes complemented by open questions (e.g. explain a concept or behaviour).

An advantage of this instrument is its versatility, in that it can be used for different types of assessment of cultural competence. When used for diagnostic assessment, it ought to include items covering all cultural fields to make it possible to determine the extent of students' knowledge of the relevant culture.

The main drawback such questionnaires entail is the complexity involved in designing them, especially those that encompass all cultural fields, as it is not easy to select items that genuinely offer a reliable insight into students' cultural knowledge. 
This is a post-print version of the following published paper:

Hurtado Albir, Amparo; Olalla-Soler, Christian (2016). " Procedures for assessing the acquisition of cultural competence in translator training", The Interpreter and Translator Trainer, Vol. 10 No. 3, pp. 318-342. https://doi.org/10.1080/1750399X.2016.1236561

Box 4. Example of a cultural knowledge questionnaire: declarative cultural knowledge questionnaire on German culture (Olalla and Neunzig in progress)

[The questionnaire comprises 4 units (natural world, behaviour, heritage and society) and has a total of 30 items. A single item per field is reproduced here].

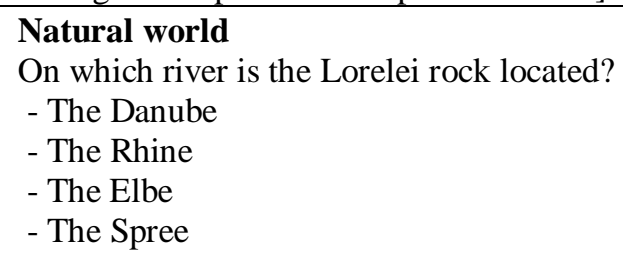

\section{Behaviour}

Which of the following statements is false? In Germany...

- time management and punctuality are considered very important.

- recycling and looking after the environment are considered very important.

- balancing work and family life is considered less important than work itself.

- social norms and behavioural models are widely respected.

\section{Heritage}

When was Germany's current constitution adopted?

- 1929

- 1949

$-1969$

$-1989$

\section{Society}

How does Germany hope to change its energy model between now and 2022?

- Cease using solar power

- Phase out nuclear power

- Extract gas from the Arctic

- Introduce fracking in its Länder

Assessable aspects include:

- correctness of answers;

- information quality (in the case of open questions).

This instrument can be used to assess cultural knowledge.

\subsection{Translation Process Recordings}

A recording (made with a program such as Camtasia or Translog) of an individual's on-screen activity while they translate can be used as an instrument for assessing the acquisition of cultural competence. A student may view recordings of their own translation process or those of others (e.g. other students, professional translators) for analysis and/or comparison purposes.

It is possible to use such recordings for assessment in different ways, as they can provide:

(1) Information on the translation process a student has followed to resolve cultural references, complementing that obtainable from the translation itself. In this case, recordings are an alternative or a complement to students' translation reports.

Assessable aspects include:

- documentation strategies (resources used and type of queries performed);

- provisional solutions (other solutions considered);

- time taken (total time and time spent on cultural references);

- distribution of stages (orientation, development, revision). 
This is a post-print version of the following published paper:

Hurtado Albir, Amparo; Olalla-Soler, Christian (2016). " Procedures for assessing the acquisition of cultural competence in translator training", The Interpreter and Translator Trainer, Vol. 10 No. 3, pp. 318-342. https://doi.org/10.1080/1750399X.2016.1236561

(2) Information on a student's ability to reflect on the translation process followed to resolve cultural references, be it their own (self-assessment) or that of another individual. In this case, the student writes a report on the recordings they view. A worksheet with questions can be used to guide them in producing their report.

Assessable aspects include:

- translation process description (correct options chosen and errors made in the process; strategies used; documentation used and queries performed; time spent on each stage; changes made; etc.);

- report composition, structure and presentation.

It is also possible to use other instruments, such as TAPs ( $\mathrm{Li} \mathrm{2011),} \mathrm{to} \mathrm{capture} \mathrm{details} \mathrm{of} \mathrm{the}$ translation process. For example, students can record everything they say while translating and subsequently use the recordings to write a report on their translation process.

This instrument can be used to assess cultural knowledge acquisition abilities and culturerelated contrastive abilities.

\subsection{Psychometric Tests}

Psychometric tests are mainly used to measure attitudes. They are frequently used in Intercultural Studies, a discipline within which there has been great interest in measuring the acquisition of cultural competence in the business and international relations fields (Black 1988; LaFromboise, Coleman and Hernandez 1991; Pruegger and Rogers 1993; Rathje 2007; among others) and in foreign language training (Olebe and Koester 1989; Fantini 1995; among others).

The aspects that such tests measure include attitudes towards other cultures (flexibility, openness, sociability, etc.), abilities (using cultural knowledge to resolve situations involving cultural conflict, adapting behaviour to target culture norms, etc.), and traits such as resistance to prejudices (Cartwright 2012; Devine et al. 2012; among others). A list of different psychometric tests can be found in Fantini (2009, 466-474). Below, we present the three that we feel are best suited to translator training:

- Multicultural Personality Questionnaire (van der Zee and van Oudenhoven 2001, 286287): for measuring attitudes such as flexibility, open-mindedness, social initiative, cultural empathy and emotional stability.

- Behavioral Assessment Scale for Intercultural Communication (Koester and Olebe 1988): for measuring intercultural behaviours such as displaying respect, orientation to knowledge, empathy, interaction management, task role behaviour, relational role behaviour, tolerance for ambiguity and interaction posture.

- Project Implicit Social Attitudes (Harvard University, University of Virginia and University of Washington): for measuring unconscious stereotypes and prejudices related to social attitudes, covering topics such as race, gender and sexual orientation. 
This is a post-print version of the following published paper:

Hurtado Albir, Amparo; Olalla-Soler, Christian (2016). " Procedures for assessing the acquisition of cultural competence in translator training", The Interpreter and Translator Trainer, Vol. 10 No. 3, pp. 318-342. https://doi.org/10.1080/1750399X.2016.1236561

Assessable aspects include:

- empathy with members of other cultures;

- adaptation to different cultural situations;

- handling of situations involving cultural conflict;

- resistance to stereotypes.

Box 5. Example of a psychometric test: Multicultural Personality Questionnaire (Van der Zee and van Oudenhoven 2001, 286-287)

[The full version of this test comprises 78 items. Here, we present examples from its Cultural Empathy and Openmindedness scales].

\begin{tabular}{|c|c|c|c|c|c|}
\hline \multicolumn{6}{|c|}{$\begin{array}{l}\text { To what extent do the following statements apply to you? (Please circle the answer that is most } \\
\text { applicable to you). }\end{array}$} \\
\hline & $\begin{array}{c}\text { not at all } \\
\text { applicable }\end{array}$ & & & & $\begin{array}{c}\text { totally } \\
\text { applicable }\end{array}$ \\
\hline \multicolumn{6}{|l|}{ Cultural Empathy (14 items) } \\
\hline Notices when someone is in trouble & 1 & 2 & 3 & 4 & 5 \\
\hline Understands other people's feelings & 1 & 2 & 3 & 4 & 5 \\
\hline Takes other people's habits into consideration & 1 & 2 & 3 & 4 & 5 \\
\hline Has problems assessing relationships & 1 & 2 & 3 & 4 & 5 \\
\hline \multicolumn{6}{|l|}{ Open-mindedness (14 items) } \\
\hline Gets involved in other cultures & 1 & 2 & 3 & 4 & 5 \\
\hline Finds other religions interesting & 1 & 2 & 3 & 4 & 5 \\
\hline $\begin{array}{l}\text { Seeks contact with people from a different } \\
\text { background }\end{array}$ & 1 & 2 & 3 & 4 & 5 \\
\hline Has a broad range of interests & 1 & 2 & 3 & 4 & 5 \\
\hline
\end{tabular}

This instrument can be used to assess attitudinal sub-competence.

\subsection{Cultural Portfolios}

Portfolios are an excellent competence assessment instrument as they allow for the integration of various (specific and general) competences (Bonsón and Benito 2005; Kelly 2005; Hurtado Albir 2007, 2008, 2015a, 2015b; Galán-Mañas and Hurtado Albir 2015; Galán-Mañas in press; etc.).

A portfolio contains products chosen by a student to illustrate their progress over a given period. The student must select the products to include in the portfolio and reflect on tasks they have performed during a course to show what they have learned. It is important that the students explicate the reasons for their choices and include a self-assessment report on their learning process, along with their thoughts on carrying out the tasks they have chosen (difficulties encountered, errors made, etc.) and, where possible, corrections of any errors made.

It is possible to produce portfolios specifically for assessing the acquisition of cultural competence, as illustrated in Box 6.

\section{Box 6. Example of a cultural portfolio}

- A selection of tasks performed during a course and related to cultural problems (translations, revisions,
commented translations, questionnaires, etc.), including corrections of any errors made.
- $\quad$ Reasons for choosing the relevant tasks.
- A catalogue of cultural references encountered in tasks performed during the course.
- A selection of preferred documentary resources for resolving cultural problems, plus reasons for choosing
them.
A self-assessment report on the process of learning to resolve cultural problems.


This is a post-print version of the following published paper:

Hurtado Albir, Amparo; Olalla-Soler, Christian (2016). " Procedures for assessing the acquisition of cultural competence in translator training", The Interpreter and Translator Trainer, Vol. 10 No. 3, pp. 318-342. https://doi.org/10.1080/1750399X.2016.1236561

Assessable aspects include:

- $\quad$ selection of tasks;

- reasons for choosing tasks;

- reflection on the chosen tasks;

- identification and correction of any errors made when performing the chosen tasks;

- catalogue quality (see previous section on catalogues);

- quality and variety of the documentary resources selected;

- self-assessment report on the learning process (information on what has been learned, what remains to be learned and what could be learned more comprehensively; main difficulties encountered; and possible means of improvement);

- portfolio composition, structure and presentation.

This instrument can be used to assess all the sub-competences of cultural competence.

\subsection{Recapitulation}

By way of conclusion, in Table 3 we present the sub-competences included in our proposal, along with their components, which can be used as indicators for assessment purposes, and the various tasks that can be used to assess them. The third column specifies which indicators each task may be applied to. The number of indicators assessable will, of course, vary according to the specific nature of each task (type of cultural portfolio, type of catalogue, etc.).

\section{Conclusions}

In this paper, on the basis of our integrative conception of culture, we have argued that translators' cultural competence comprises not only knowledge but also abilities and attitudes. With that in mind, we have proposed four sub-competences (cultural knowledge, cultural knowledge acquisition abilities, culture-related contrastive abilities, and attitudinal subcompetence) and various indicators for teaching cultural competence in translator training, plus procedures (instruments and tasks) for its assessment. The procedures in question correspond to a dynamic, multidimensional, criteria-based approach to assessment, where assessment is regarded as a tool for learning, one designed to evaluate products and processes, as well as knowledge, abilities and attitudes.

Nonetheless, our proposal should be empirically validated. That would involve carrying out experiments with professional translators and translation students (as has been done in OlallaSoler 2015; in press) to validate our proposed model of cultural competence. We would also need to collect information regarding the suitability of the assessment procedures we have put forward from students and lecturers (by means of questionnaires, interviews, discussion groups, etc.). Additionally, it would be necessary to perform experiments involving large, 
This is a post-print version of the following published paper:

Hurtado Albir, Amparo; Olalla-Soler, Christian (2016). " Procedures for assessing the acquisition of cultural competence in translator training", The Interpreter and Translator Trainer, Vol. 10 No. 3, pp. 318-342. https://doi.org/10.1080/1750399X.2016.1236561

Table 3. Cultural competence assessment in translator training: sub-competences and assessment tasks

\begin{tabular}{|c|c|c|}
\hline SUB-COMPETENCE & ASSESSMENT TASKS & $\begin{array}{l}\text { COMPONENTS } \\
\text { (ASSESSABLE } \\
\text { INDICATORS) }\end{array}$ \\
\hline \multirow{6}{*}{$\begin{array}{l}\text { Cultural knowledge } \\
\text { Components (assessable indicators): } \\
\text { (1) Knowing about the organisation of the natural } \\
\text { environment } \\
\text { (2) Knowing about the organisation of cultural heritage } \\
\text { (3) Knowing about the organisation of society } \\
\text { (4) Knowing about communicative requirements } \\
\text { (5) Being familiar with models of behaviour, values } \\
\text { and ideas }\end{array}$} & Text analysis (Section 4.1) & All \\
\hline & $\begin{array}{l}\text { Reports on texts } \\
\text { (Section 4.1) }\end{array}$ & All \\
\hline & $\begin{array}{c}\text { Commented translation } \\
\text { (Section 4.3) }\end{array}$ & All \\
\hline & $\begin{array}{c}\text { Reports on cultural } \\
\text { references (Section 4.4) }\end{array}$ & All \\
\hline & $\begin{array}{c}\text { Cultural knowledge } \\
\text { questionnaires (Section 4.6) }\end{array}$ & All \\
\hline & $\begin{array}{c}\text { Cultural portfolio } \\
\text { (Section 4.9) }\end{array}$ & All \\
\hline \multirow{5}{*}{$\begin{array}{l}\text { Cultural knowledge acquisition abilities } \\
\text { Components (assessable indicators): } \\
\text { (1) Identifying documentation-related needs } \\
\text { (2) Planning searches to enhance effectiveness } \\
\text { (3) Wording queries appropriately to perform effective } \\
\text { searches } \\
\text { (4) Evaluating documentation sources } \\
\text { (5) Evaluating search results } \\
\text { (6) Applying search improvement procedures } \\
\text { (7) Broadening the range of documentation sources } \\
\text { used }\end{array}$} & $\begin{array}{c}\text { Commented translation } \\
(\text { Section 4.3) }\end{array}$ & All \\
\hline & $\begin{array}{c}\text { Reports on cultural } \\
\text { references (Section } 4.4 \text { ) }\end{array}$ & All \\
\hline & $\begin{array}{l}\text { Catalogue of cultural } \\
\text { references (Section 4.5) }\end{array}$ & All \\
\hline & $\begin{array}{l}\text { Translation process } \\
\text { recording analysis } \\
\text { (Section 4.7) }\end{array}$ & All \\
\hline & $\begin{array}{l}\text { Cultural portfolio } \\
\text { (Section 4.9) }\end{array}$ & All \\
\hline \multirow{9}{*}{$\begin{array}{l}\text { Culture-related contrastive abilities } \\
\text { Components (assessable indicators): } \\
\text { (1) Anticipating possible translation problems caused } \\
\text { by cultural interference } \\
\text { (2) Using knowledge about the source and target } \\
\text { cultures to identify, interpret and evaluate cultural } \\
\text { references } \\
\text { (3) Checking cultural references against knowledge of } \\
\text { the source and target cultures } \\
\text { (4) Using appropriate strategies to resolve cultural } \\
\text { translation problems }\end{array}$} & Text analysis (Section 4.1) & 2 and 3 \\
\hline & $\begin{array}{c}\text { Commentaries on texts } \\
(\text { Section 4.1) }\end{array}$ & 1,2 and 3 \\
\hline & $\begin{array}{l}\text { Text translation } \\
\text { (Section 4.2) }\end{array}$ & 4 \\
\hline & $\begin{array}{c}\text { Translation analysis } \\
\text { (Section 4.2) }\end{array}$ & 2 and 3 \\
\hline & $\begin{array}{c}\text { Translation revision } \\
\text { (Section 4.2) }\end{array}$ & 2 and 3 \\
\hline & $\begin{array}{c}\text { Commented translation } \\
\text { (Section 4.3) }\end{array}$ & All \\
\hline & $\begin{array}{l}\text { Catalogue of cultural } \\
\text { references (Section 4.5) }\end{array}$ & 2,3 and 4 \\
\hline & $\begin{array}{c}\text { Translation process } \\
\text { recording analysis } \\
\text { (Section 4.7) }\end{array}$ & 2,3 and 4 \\
\hline & $\begin{array}{c}\text { Cultural portfolio } \\
\text { (Section 4.9) }\end{array}$ & All \\
\hline \multirow{4}{*}{$\begin{array}{l}\text { Attitudinal sub-competence } \\
\text { Components (assessable indicators): } \\
\text { (1) Being aware of the influence of one's own culture } \\
\text { on one's perception, interpretation and evaluation of } \\
\text { other cultures } \\
\text { (2) Empathising with other cultural groups } \\
\text { (3) Being flexible in situations of possible cultural } \\
\text { conflict } \\
\text { (4) Accepting cultural differences } \\
\text { (5) Accepting and modifying cultural prejudices }\end{array}$} & $\begin{array}{l}\text { Commentaries on texts } \\
(\text { Section } 4.1)\end{array}$ & All \\
\hline & $\begin{array}{l}\text { Reports on texts } \\
\text { (Section 4.1) }\end{array}$ & All \\
\hline & $\begin{array}{l}\text { Psychometric tests } \\
\text { (Section } 4.8)\end{array}$ & All \\
\hline & $\begin{array}{l}\text { Cultural portfolio } \\
\text { (Section 4.9) }\end{array}$ & All \\
\hline
\end{tabular}


This is a post-print version of the following published paper:

Hurtado Albir, Amparo; Olalla-Soler, Christian (2016). " Procedures for assessing the acquisition of cultural competence in translator training", The Interpreter and Translator Trainer, Vol. 10 No. 3, pp. 318-342. https://doi.org/10.1080/1750399X.2016.1236561

representative samples of translation students, in different contexts, to gather data on the results obtained using our assessment tasks and instruments so as to prove their efficacy.

\section{References}

Agar, Michael. 1994. Language Shock: Understanding the Culture of Conversation. New York: William Morrow and Company.

Baker, Mona. 2006. Translation and Conflict: A Narrative Account. London: Routledge.

Bell, Roger T. 1991. Translation and Translating. London: Longman.

Black, J. Steward. 1988. "Work role transitions: A study of American expatriate managers in Japan." Journal of International Business Studies (19): 277- 294.

Bonsón, Magdalena and Agueda Benito. 2005. "Evaluación y aprendizaje.” In Nuevas claves para la docencia universitaria, edited by Agueda Benito and Ana Cruz, 87-100. Madrid: Narcea.

Cao, Deborah. 1996. "Towards a model of translation proficiency." Target 8 (2): 325-340.

Cano, Elena. 2015. Evaluación de competencias en educación superior. Madrid: Arco - Muralla.

Cartwright, Chris Taylor. 2012. "Assessing the Relationship between Intercultural Competence and Leadership Styles: An Empirical Study of International Fulbright Students in the U.S." Dissertations and Theses. Paper 759.

Chesterman, Andrew. 1993. "From 'Is' to 'Ought': Translation Laws, Norms and Strategies." Target 5 (1): $1-20$.

Delisle, Jean. 1980. L'analyse du discours comme méthode de traduction. Ottawa : Éditions de l'Université d'Ottawa.

Devine, Patricia G., Patrick S. Forscher, Anthony J. Austin, and William T. L. Cox. 2012. "Long-term reduction in implicit race bias: A prejudice habit-breaking intervention." Journal of Experimental Social Psychology 48 (6): 1267-1278.

Even-Zohar, Itamar 1990. Polysystem Studies. [= Poetics Today 11:1]. Durham: Duke University Press. Hall (1959)

Fantini, Alvino E. 1995. "Language, culture, and world view: Exploring the nexus." International Journal of Intercultural Relations (19): 143-153. 
This is a post-print version of the following published paper:

Hurtado Albir, Amparo; Olalla-Soler, Christian (2016). " Procedures for assessing the acquisition of cultural competence in translator training", The Interpreter and Translator Trainer, Vol. 10 No. 3, pp. 318-342. https://doi.org/10.1080/1750399X.2016.1236561

Fantini, Alvino E. 2009. “Assessing Intercultural Competence: Issues and Tools.” In The SAGE Handbook of Intercultural Competence, edited by Darla K. Deardorff, 456-476. Thousand Oaks: SAGE Publications.

Foreign Office. 2005. Instructions for British Servicemen in Germany, 1944. London: The Bodleian Library, University of Oxford.

Friedrichs, Hauke. 2009. "Lautstark Gegen die Ostalgie.” Die Zeit Online, August 13. http://www.zeit.de/online/2009/34/berliner-mauer-streit.

Galán-Mañas, Anabel. In press. "The Learning Portfolio: a tool for assessment in competence-based translator training programs." The Interpreter and Translator Trainer 10 (2).

Galán-Mañas, Anabel, and Amparo Hurtado Albir. 2015. "Competence Assessment Procedures in Translator Training." The Interpreter and Translator Trainer 9 (1): 63-82.

García Álvarez, Ana María. 2007. "Evaluating Students' Translation Process in Specialised Translation: Translation Commentary." JoSTrans (7).

Goodenough, Ward H. 1957. "Cultural Anthropology and Linguistics." In Report of the 7th Annual Round Table Meeting on Linguistics and Language Study, edited by P. Garvin. Washington: Georgetown University.

González, Julia and Robert Wagenaar. 2003. Tuning Educational Structures in Europe. Final Report. Phase One. Bilbao: Universidad de Deusto.

Göpferich, Susanne. 2008. Translationsprozessforschung: Stand-Methoden- Perspektiven. Translationswissenschaft 4. Tübingen: Narr.

Hatim, Basil, and Ian Mason. 1997. The Translator as Communicator. London/New York: Routledge.

Hurtado Albir, Amparo. 1996. "La enseñanza de la traducción directa 'general'. Objetivos de aprendizaje y metodología.” In La enseñanza de la traducción [Col. Estudis sobre la traducció 3], edited by Amparo Hurtado Albir, 31-55. Castellón: Universitat Jaume I.

Hurtado Albir, Amparo. 2001/2011. Traducción y Traductología. Introducción a la Traductología. Madrid: Cátedra.

Hurtado Albir, Amparo. 2007. "Competence-Based Curriculum Design for Training Translators." The Interpreter and Translator Trainer 1 (2): 163-195.

Hurtado Albir, Amparo. 2008. "Compétence en traduction et formation par compétences.” TTR: Etudes sur le texte et ses transformations 21 (1): 17-64.

Hurtado Albir, Amparo. 2015a. Aprender a traducir del francés al español. Competencias y tareas para la iniciación a la traducción. Castellón/ Madrid: Universidad Jaume I - Edelsa. Includes Guía didáctica.

Hurtado Albir, Amparo. 2015b. "The Acquisition of Translation Competence. Competences, Tasks, and Assessment in Translator Training". Meta 60(2): 256-280.

Hurtado Albir, Amparo. In press. Researching Translation Competence by PACTE Group. Amsterdam/Philadelphia: John Benjamins.

Katan, David. 2001. "When Difference Is Not Dangerous: Modelling Intercultural Competence for Business." Textus XIV (2): 287-306.

Katan, David. 2008. "University training, competencies and the death of the translator. Problems in professionalizing translation and in the translation profession." In Tradurre: Formazione e Professione, edited by Maria Teresa Musacchio and Genevieve Henrot, 113-140. Padova: CLEUP.

Katan, David. 2009. "Culture”. In Routledge Encyclopedia of Translation Studies, edited by Mona Baker and Gabriela Saldanha, 70-74. 2nd ed. London/New York: Routledge

Katan, David. 2009. “Translator Training and Intercultural Competence." In La Ricerca Nella Comunicazione Interlinguistica. Modelliteorici E Metodologici, edited by Stefania Cavagnoli and Elena Di Giovanni, 282-301. Milan: Franco Angeli.

Kelly, Dorothy. 2005. A Handbook for Translator Trainers. Manchester: St Jerome.

Kiraly, Donald. 1995. Pathways to Translation. Pedagogy and Process. Kent, OH: The Kent State University Press.

Koester, Jolene, and Margaret Olebe. 1988. "The Behavioral Assessment Scale for Intercultural Communication Effectiveness.” International Journal of Intercultural Relations 12 (3): 233-246. 
This is a post-print version of the following published paper:

Hurtado Albir, Amparo; Olalla-Soler, Christian (2016). " Procedures for assessing the acquisition of cultural competence in translator training", The Interpreter and Translator Trainer, Vol. 10 No. 3, pp. 318-342. https://doi.org/10.1080/1750399X.2016.1236561

Kroeber, Alfred L., and Clyde Kluckhohn. 1952. Cultures: A Critical Review of Concepts and Definitions. Cambridge: Harvard University. Papers of the Peabody Museum of Archaeology and Ethnology, Vol. XLVII, No 1.

LaFromboise, Teresa D., Hardin L. K. Coleman, and Alexis Hernandez. 1991. "Development and factor structure of Cross-Cultural Counselling Inventory-Revised." Professional Psychology: Research and Practice 22 (5): 380-388.

Lasnier, François. 2000. Réussir la formation par compétences. Guérin: Montreal.

Lefevere, André, and Susan Bassnett. 1990. "Introduction: Proust's Grandmother and the Thousand and One Nights: The 'Cultural Turn' in Translation Studies”. In Translation, History and Culture, edited by Susan Bassnett and André Lefevere, 1-13. London \& New York: Pinter.

Li, Dechao. 2011. "Think-aloud teaching in translation class: implications from TAPs translation research". Perspectives: Studies in Translatology 19(2): 109-122.

Molina, Lucía. 2001. "Análisis descriptivo de la traducción de los culturemas árabe-español.” PhD diss., Universitat Autònoma de Barcelona.

Neubert, A. 2000. "Competence in language, in languages, and in translation." In Developing Translation Competence, edited by Christina Schäffner and Beverly Adab, 3-18. Amsterdam/Philadelphia: John Benjamins.

Newmark, Peter. 1988. A Textbook of Translation. Prentice Hall: Hemel Hempstead.

Nida, Eugene A. 2005. Language, Culture and Translation. Shanghai: Shanghai Foreign Language Education Press.

Nord, Christiane. 2005. Text Analysis in Translation. $2^{\text {nd }}$ ed. Amsterdam: Rodopi.

Olalla-Soler, Christian, and Wilhelm Neunzig. In progress. "Measuring Trainee Translators' Knowledge of German Culture: Design and Validation of a Cultural Declarative Knowledge Questionnaire."

Olalla-Soler, Christian. 2015. "An Experimental Study into the Acquisition of Cultural Competence in Translator Training. Research Design and Methodological Issues." Translation \& Interpreting 7 (1): 86-110.

Olalla-Soler, Christian. In press. "Un estudio experimental sobre la adquisición de la competencia cultural en la formación de traductores. Resultados del estudio piloto." Meta.

PACTE. 2003. "Building a Translation Competence Model.” In Triangulating Translation: Perspectives in Process Oriented Research, edited by Fabio Alves, 43-66.Amsterdam: John Benjamins.

PICT. 2012. Intercultural Competence Curriculum Framework. Accessed 13 October 2015. http://www.pictllp.eu/download/PICT_Curriculum_Framework.pdf

Presas, Marisa. 2012. "Training Translators in the European Higher Education Area: A Model for Evaluating Learning Outcomes". The Interpreter and Translator Trainer 6 (2): 138-169.

Pruegger, Valerie J., and Tim B. Rogers. 1993. "Development of a scale to measure cross-cultural sensitivity in the Canadian context." Canadian Journal of Behavioural Science (25): 615-621.

Pym, Anthony. 1992. "Translation Error Analysis and the Interface with Language Teaching." In Teaching Translation and Interpreting: Training, Talent and Experience, edited by Cay Dollerup and Anne Loddegaard, 279-288. Amsterdam/Philadelphia: John Benjamins.

Rathje, Stefanie. 2007. "Intercultural competence: The status and future of a controversial concept." Language and Intercultural Communication (7): 254-266.

Risku, Hanna. 1998. Translatorische Kompetenz. Kognitive Grundlagen des Übersetzens als Expertentätigkeit. Tübingen: Stauffenberg Verlag.

Robinson, Gail. 1988. Crosscultural understanding. Hemel Hempstead: Prentice Hall International.

Schäffner, Christina. 2004. "Understanding Bohemian Villages... and Greek. Cultural Competence in Translation." In Translating in the 21st Century: Trends and Prospects, edited by G. Androulakis, 486-494. Thessaloniki: University Studio Press.

Shreve, Gregory M. 2006. "The deliberate practice: translation and expertise." Journal of Translation Studies 9 (1): 27-42. 
This is a post-print version of the following published paper:

Hurtado Albir, Amparo; Olalla-Soler, Christian (2016). " Procedures for assessing the acquisition of cultural competence in translator training", The Interpreter and Translator Trainer, Vol. 10 No. 3, pp. 318-342. https://doi.org/10.1080/1750399X.2016.1236561

Taft, Ronald. 1981. "The Role and Personality of the Mediator." In The Mediating Person: Bridges between Cultures, edited by Stephen Bochner, 53-88. Cambridge: Schenkman.

Toury, Gideon. 1995. Descriptive Translation Studies and Beyond. Amsterdam \& Philadelphia: John Benjamins.

Tylor, Edward Burnett. 1871. Primitive Culture: Researches into the Development of Mythology, Philosophy, Religion, Art, and Custom, Volume 1. London: John Murray.

van der Zee, Karen I., and Jan Pieter van Oudenhoven. 2001. "The Multicultural Personality Questionnaire: Reliability and Validity of Self- and Other Ratings of Multicultural Effectiveness." Journal of Research in Personality 35: 278-288.

Venuti, Lawrence. 1998. The Scandals of Translation. London: Routledge.

Vermeer, Hans J. 1989. Kulturspezifik des translatorischen Handelns. Heidelberg: mimeo.

Vermeer, Hans J. 1992. "Is Translation a Linguistic or a Cultural Process?" Ilha Do Desterro. A Journal of English Language, Literatures in English and Cultural Studies (28): 37-51.

Witte, Heidrun. 1987. "Die Kulturkompetenz des Translators - Theoretisch-abstrakter Begriff oder realisierbares Konzept?”. TEXTconTEXT 2 (2): 109-136.

Witte, Heidrun. 2000. Die Kulturkompetenz des Translators. Tübingen: Stauffenberg Verlag.

Yániz, Concepción and Lourdes Villardón. 2006. Planificar desde competencias para promover el aprendizaje. Bilbao, Universidad de Deusto. 